2013

\title{
Cultural Diplomacy in US-Japanese Relations, 1919-1941
}

Hiroshi Kitamura

William \& Mary, hxkita@wm.edu

Follow this and additional works at: https://scholarworks.wm.edu/aspubs

\section{Recommended Citation}

Kitamura, H. (2013). Jon Thares Davidann. Cultural Diplomacy in US-Japanese Relations, 1919-1941.

This Article is brought to you for free and open access by the Arts and Sciences at W\&M ScholarWorks. It has been accepted for inclusion in Arts \& Sciences Articles by an authorized administrator of W\&M ScholarWorks. For more information, please contact scholarworks@wm.edu. 
cultural context to specific socioeconomic themes within the period is a viable way to try to prove a nonevent. Vitally, Gorman's study also shows the worth of studying things that do not happen in order to gauge the "rightness" of decision-making given the possible courses of action. His decision to end the book with the signing of the Kellogg-Briand Pact in 1928 makes sense. Changes in the international system in the 1930 s weakened the diplomatic influence of the pact's supporters; ultimately they failed to direct world affairs as they had hoped.

Gorman does an outstanding job of investigating the Anglo-American attempt to construct an international society in the post-World War I era. His research is multinational, multi-archival, and multidisciplinary, having intellectual depth and breadth. Gorman brings a political scientist's sensibility to bear on the evidence, weaving aspects of religion, culture, sport, and social and political activism into a rich tapestry of ideas and beliefs. He explores a range of class issues related to the various elites present on both sides of the Atlantic, complementing that analysis with insights regarding the evolution of middle-class political awareness and involvement in international affairs. Greater public desire to influence international relations in the pursuit of peace and stability reached its high-water mark in the Kellogg-Briand Pact. The roots of post-World War II Anglo-American direction of international governance and globalization, Gorman argues, are to be found here.

Overall the argument is compelling and presented in a convincing manner. My only quibbles concern the definition of what a society is and what it is supposed to do, and the author's equation of an Atlanticist focus with one that is truly international. A more sophisticated and better-developed sense of what an international society based on 1920 norms might be like, coupled with a more nuanced discussion of what that society expected to achieve, would provide a metric for judging levels of success or failure. Finally, the ever-present reality of racism and its influence on the internationalist movement is not dealt with in any significant way. This, in conjunction with Gorman's failure to include the rise of Russian, Japanese, and Chinese influence, makes his focus Atlanticist rather than international.

There is no doubt, however, that this book makes an important contribution to the literature on interwar international relations. It deserves a place on the bookshelves of historians interested in exploring relations between states in the 1920 s as it gives insight into the process of globalization that continued in the postWorld War II and post-Cold War eras.

GREg KenNedy

King's College London

Jon Thares Davidann. Cultural Diplomacy in U.S.-Japanese Relations, 1919-1941. New York: Palgrave Macmillan. 2007. Pp. 262. \$95.00.

How and why did the United States and Japan go to war? Jon Thares Davidann revisits this classic question in a study of cross-cultural imaginings and encounters between the two societies. Complementing standard works that focused on formal diplomacy and state-running elites, his lucid, staccato-paced volume examines the role of "public opinion" and "private citizen diplomacy" (p. 2) in the making and breaking of this bilateral relationship.

Davidann argues that the "unofficial" relationship of the U.S. and Japan began in the wake of Commodore Matthew C. Perry's "opening" of Japan. As the once self-isolated society quickly transformed into a "modern" industrial nation, a growing number of Americans sought to build amicable ties with the Japanese. The engine of this movement was a group of Christian missionaries such as Sidney Gulick and Sherwood Eddy, who viewed Japan (a little naïvely) as a budding democratic nation. In Japan, a community of liberals-most notably Tsurumi Yusuke and Nitobe Inazo-welcomed these U.S. overtures and strove to foster goodwill from the other side of the Pacific. The two sides converged at the Institute of Pacific Relations, a forum designed to improve bilateral relations through dialogue and cooperation. Its 1929 meeting in Kyoto, argues Davidann, marked the "high point of unofficial diplomacy" between the two countries (p. 131).

The advocates of cross-cultural exchange, however, faced a wall of obstacles. While liberal internationalists were reaching out across the Pacific, the U.S. press often cast a skeptical eye on Japan, painting it as a rising military threat built on unchanging Shintoist and "feudalistic" beliefs. The arrival of Japanese immigrants in Hawai'i and the West Coast triggered fears of a "yellow peril" and fueled a powerful anti-immigration campaign in the United States. The Kwangtung Army's aggression in Manchuria planted further distrust in the minds of Americans, even while liberal missionaries maintained their sympathy toward the Japanese.

The informal relationship crumbled from the Japanese side as well. The years following the immigration controversy saw a rise of right-wing tendencies in the Japanese government. This climate fueled the passion of conservatives, who avidly supported the imperial cause. Liberals such as Nitobe sought to repair the ailing alliance, but did so while defending Japanese state policy. The second Sino-Japanese War virtually "destroyed" (p. 205) the informal rapport of the two societies. Private, person-to-person diplomacy proved powerless and futile against official agendas as the reluctant Roosevelt administration began to confront the East Asian threat and as the Japanese government effectively rallied the public through propaganda, censorship, and political pressure. It was a matter of time for the war to break out-eventually on December 7, 1941.

Davidann's study has good things to offer. Written in crisp and smooth prose, it revisits the interwar era through a careful analysis of English-language sources. Admirably impartial toward the individuals in discussion, Davidann not only highlights internationalist and nationalist tendencies in every phase of the tense two decades but also teases out the prejudices and misun- 
derstandings of both liberals and conservatives. Avoiding deterministic overtones, he successfully captures the complex thoughts and motives of key American and Japanese observers-most notably Charles A. Beard, John Dewey, Gulick, Nitobe, Henry L. Stimson, and Tsurumi.

Yet the breadth in chronology may have forced some sacrifices in depth. On the U.S. side, the book's primary focus on white men leaves us wanting to know more about the cross-cultural perspectives of women (which is covered marginally) and people of color (particularly African Americans). On the Japanese side, the sole use of English-language materials opens questions about the range of Japanese "public opinion." Here, too, one can ask about female bridge figures such as Ichikawa Fusae and Sakanishi Shiho as well as male critics who wielded wide influence in Japanese society (e.g., Mufofuse Koshin and Oya Soichi). Moreover, the book largely limits itself to the discourse of Japanese intellectuals, politicians, and journalists - the "elites." In assessing "popular" sentiment toward U.S. policies and values, it would be of merit to turn greater attention to the wider consumers of American music, fashion, movies, and sports (especially baseball)—which appears to have remained popular in Japan even after official relations began to sour in the 1930s.

Such questions and quibbles aside, this carefully crafted book about the U.S.-Japanese "road to war" insightfully exposes the limits of unofficial diplomacy in the face of state-driven conflicts. It also illustrates the significance of private individuals in shaping cross-cultural exchange in a rapidly changing world. The end result is an engaging study that delivers useful knowledge to students and scholars of transpacific and international history prior to World War II.

Hiroshi Kitamura

College of William and Mary

S. C. M Paine. The Wars for Asia, 1911-1949. New York: Cambridge University Press. 2012. Pp. xvi, 487. \$37.99.

S. C. M. Paine sets out to show the close linkages among the Chinese civil war, the East Asian regional war (Japan versus both China and Russia), and the global war (World War II). Suggestively, she sees three "levels" of these wars as "nested," with each being a part of the others and each having many, often tragic, implications for the others (pp. 9-11). Paine's synthesis indeed compels the reader to see these wars in a new light; although there are not many analytical breakthroughs here, the whole seems greater than the sum of its parts.

This book is mostly a chronicle that piles fact upon fact, often in an overwhelming degree of detail: battle follows battle follows battle. The author focuses on countries, political leaders and strategies, economic goals, and policies. The "people" receive an occasional nod but are generally bit players, reacting to situations and to their leaders; as a group, they are little differentiated. Two examples make the point. Paine notes that during the "great rebellions" of the nineteenth cen- tury, "many Chinese" thought the declining stage of the Qing dynastic cycle was occurring (p. 268). Who is meant by "many Chinese"? How many Chinese conceived of a "dynastic cycle"? How many placed their lives into such a paradigm? Or again, "the masses ... concluded that the Communists ... held the mandate of Heaven" (p. 268). Were "the masses" really concerned about the mandate of Heaven? Was that conception truly a motivating factor in their political, social, and economic choices?

Paine makes nomenclature of political movements an important point but without clearly defining the parameters of "incident," battle, rebellion, civil war, revolution, and war in general. Part of this reflects the perspectives of the East Asian antagonists who chose to name events so as to reflect their own views and to propagandize their actions in certain ways. But the author is not consistent here. She accuses the Chinese (p. 109) of giving the name "rebellion" to many mid-nineteenthcentury movements that were really, she argues, "civil wars" (including the Boxer uprising, which only involved a few provinces in north China). But in a later analysis (p. 268), Paine does not hesitate to call these "civil wars," as she had analyzed them, simply "the great rebellions." In her treatment of the early republic, she readily identifies three "revolutions"-in 1911, 1913, and 1915-pointedly not rebellions or civil wars, but she does not explain what made each of them a "revolution" (pp. 111-112).

Paine's strongest points concern the regional and global wars. Her treatment of Japanese and Russian aims and strategies, of the role of the United States, and of the tragedy of the Chinese regional and civil wars is perceptive; especially good in this regard is the first part of her conclusion (pp. 271-282). But the book is marred by the irritating repetition of events and their meanings, probably a result of the author's choice of organization. There are errors and inconsistencies in the coverage of Chinese domestic affairs. For a few examples, Hu Hanmin was not the leader of the Western Hills group (p. $50)$; Chiang did not return from the Soviet Union in 1923 "favorably impressed" (p. 51). On page 57, the reader learns that Chiang "had eliminated, neutralized, or co-opted his most powerful warlord rivals," only to read a few pages later (pp. 64-65) that this was not the case. Chiang's successes in state-building are applauded (p. 57) but then downplayed (pp. 68-69). Many historians would find that the "Nationalists paid careful attention to the rural crisis" (p. 62) a novel idea. Moreover, the author's written style seems breezily intemperate. Wuhan was "ground zero [my emphasis] for the death of the dynastic system" (p. 52); Chiang's 1927 launching of the White Terror is described as his "[taking] a breather to clean house" (p. 53); the Soong sister who married H. H. Kung was the "least seductive" of the three sisters (p. 55); and "[i]f the Communists had their way, entire social classes were slated for death" (p. 115).

Paine's most important contribution is in dealing (however briefly) with the intangibles of war. She shows 